\title{
Prioritizing erosion-prone area through morphometric analysis: an RS and GIS perspective
}

\author{
Sarita Gajbhiye $\cdot$ S. K. Mishra $\cdot$ Ashish Pandey
}

Received: 5 April 2013/Accepted: 9 September 2013/Published online: 25 September 2013

(c) The Author(s) 2013. This article is published with open access at Springerlink.com

\begin{abstract}
The geomorphological characteristics of a watershed are more commonly used for developing the regional hydrological models for solving various hydrological problems of the ungauged watersheds in inadequate data situations. Therefore, in this study to find out the most vulnerable sub-watershed to soil erosion, morphometric analysis and prioritization were carried out on 14 subwatersheds of Manot River catchment, which is a tributary of the Narmada River. The morphometric parameters considered for analysis are stream order, stream length, stream frequency, drainage density, texture ratio, form factor, circulatory ratio, elongation ratio, bifurcation ratio and compactness ratio. After analysis of morphometric parameters, compound parameter values are calculated and prioritization rating of 14 sub-watersheds is carried out. The subwatershed 13 that has the lowest compound parameter value of 3.63 is likely to be subjected to maximum soil erosion; hence, it requires immediate attention to providing soil conservation measures. Morphological parameters-based prioritization is in good agreement with the geological field investigation carried out during the field work.
\end{abstract}

Keywords Morphometric analysis - Soil erosion . Prioritization · GIS · Soil conservation

\section{Introduction}

Availability of natural resources, i.e., land and water is decreasing day by day, due to growing population pressure.

S. Gajbhiye $(\bowtie) \cdot$ S. K. Mishra · A. Pandey

Department of Water Resource Development and Management,

IIT, Roorkee, India

e-mail: gajbhiyesarita@gmail.com
So, planning and management of these natural resources is the need of the hour. Proper scientific planning and management of these resources requires immense data. Therefore, geomorphological characteristics of a watershed are commonly used for developing the regional hydrological models for solving various hydrological problems of the ungauged watersheds or inadequate data situations. Applications of geographical information system (GIS) techniques are much efficient, time-saving and suitable for spatial planning. GIS can handle complex issues and large databases for manipulation and retrieval. The use of computer has made GIS automated and today the technique is not only capable of handling large datasets, but can also solve many complex issues besides facilitating retrieval and querying of data.

Population pressure has been increasing over the years resulting in the scarcity of availability of land and water resources. Industrial expansion is also a need of the time, which requires infrastructural facilities; which intern forms a feed back resulting in further pressure on finite land and water resources. About $53 \%$ of the total area of India which is $172 \mathrm{~m}$ ha suffers from serious soil erosion and other forms of degradation. In a country like India that supports $16 \%$ of the world's population on $2 \%$ of the global land area, the problem is serious (Sebestain et al. 1995). So, planning and management of land and water resources on a sustained basis without deterioration and with constant increase in productivity is the mainstay for mankind. For their efficient and sustainable management, one has to look for a sustainable unit, so that these resources can be handled and managed effectively. The watersheds or hydrological units are considered efficient and appropriate for the necessary survey and investigation of the assessment of these resources and subsequent planning and implementation of various development programs such as soil and water conservation, command area development, erosion control 
in catchment rivers, dry land/rain-fed farming and reclamation of ravine lands. The hydrologic units are equally important for the development of water resources through major, medium and minor storage projects as well as farmlevel water harvesting structures. So, the watershed approach is more rational, because land and water resources have optimum interaction and synergetic effect when developed on the watershed basis.

An accurate understanding of the hydrological behavior of watershed is important for effective management. Intensive study of individual watershed is therefore necessary for developing a management plan, which requires immense data. In India most of the watersheds are ungauged. So, the morphometric analysis of watershed can play an important role in inadequate data collection. The morphometric characteristics of a watershed represents its attributes and can be helpful in synthesizing its hydrological behavior (Pandey et al. 2004). It is very difficult to develop a large area in one stretch, due to some geoenvironmental or economic conditions. So, there is a need to prioritize the area while applying the developmental program. Studies conducted by Sanware et al. (1988), Prasad et al. (1992) and Sharda et al. (1993) revealed that remote sensing and GIS techniques were of great use in characterization and prioritization of watershed areas. Chaudhary and Sharma (1998) carried out their study in Giri River catchment of North Himalayas for erosion hazard assessment and treatment prioritization. Using morphometric parameters and $\mathrm{F}$ factor approach, critical sub-watersheds of Dikrong River basin of Eastern Himalayas suffering from maximum soil erosion were identified (Dabral and Pandey 2007). Morphometric parameters were used to prioritize the five sub-watersheds of the Sarpha River drainage basin of Shahdol of the District of Madhya Pradesh using GIS technique by Sharma et al. (2008).

The present study is focused on prioritization of 14 subwatersheds of the Manot watershed of Mandla District, Madhya Pradesh, India, based on GIS concept through morphometric analysis. Morphometric analysis and prioritization of watersheds are very important for water resource modeling and flood management (Youssef et al. 2011; Miller and Craig 2010; Bali et al. 2012). It includes identification and evaluation of watershed which contributes to excessive erosion losses using faster and indirect methods and established relationships. This will prove to be helpful in cases which are, as the present case is, remotely placed and for those for which no other direct observational setup is available. Prioritizing erosion-prone areas in the catchment is essential when financial resources for executing a conservation plan are limited. The areas most likely to contribute to a large volume of sediment, and which are susceptible to a high degree of erosion, get higher priority in treatment.

\section{Study area}

The Narmada catchment up to Manot is located in Mandla District of Madhya Pradesh and is bounded between northern latitudes $22^{\circ} 26^{\prime}-23^{\circ} 18^{\prime}$ and eastern longitudes $80^{\circ} 24^{\prime}-81^{\circ} 47^{\prime}$ as in Fig 1 . This figure also shows the digitized stream network. The length of River Narmada from its origin up to Manot is about $269 \mathrm{~km}$ with a drainage area of $4,884 \mathrm{~km}^{2}$. The catchment is covered by forest and its topography is hilly. Its elevation ranges from $450 \mathrm{~m}$ near the Manot site to $1,110 \mathrm{~m}$ above mean sea level in the upper part of the catchment. It has continental type of climate classified as sub-tropical and sub-humid with average annual rainfall of $1,596 \mathrm{~mm}$. It is very hot in summer and cold in winter. In the major part of the catchment, soils are red, yellow and medium black with shallow to very shallow depth. In some small pockets of plain land, soils are moderately deep dark grayish clay. Approximately, $52 \%$ of the catchment area is under cultivation, about $35 \%$ under forest and $13 \%$ under wasteland (State Statistical Report 2010).

\section{Materials and methods}

The watershed boundary of the study area was automated delineated using SRTM data and is readily available on the website (http://www.gdem.aster.ersdac.or.jp). The delineated watershed boundary was further subdivided into subwatersheds (Fig 2). Morphometric analysis was carried out for their $14 \mathrm{n}$ sub-watersheds. The parameters computed in the present study using GIS technique include area, perimeter, stream order, stream length, stream number and elevation, which were obtained from the digitized coverage of the drainage network map. However, bifurcation ratio, drainage density, stream frequency, texture ratio, form factor, circulatory ratio, elongation ratio and compactness ratio were calculated by standard formulae as given in the subsequent text in "Morphometric analysis". The methodology used in this study is shown in Fig. 3.

Morphometric analysis

Quantitative analysis is very advantageous as the basin variables derived are in the form of ratios or dimensionless numbers, thus providing an effective comparison regardless of scale.

Stream order

The first step in morphometric analysis of a drainage basin is the designation of stream order; stream ordering as suggested by Strahler (1964) was used for this study. Streams that originate at a source are defined as first-order 

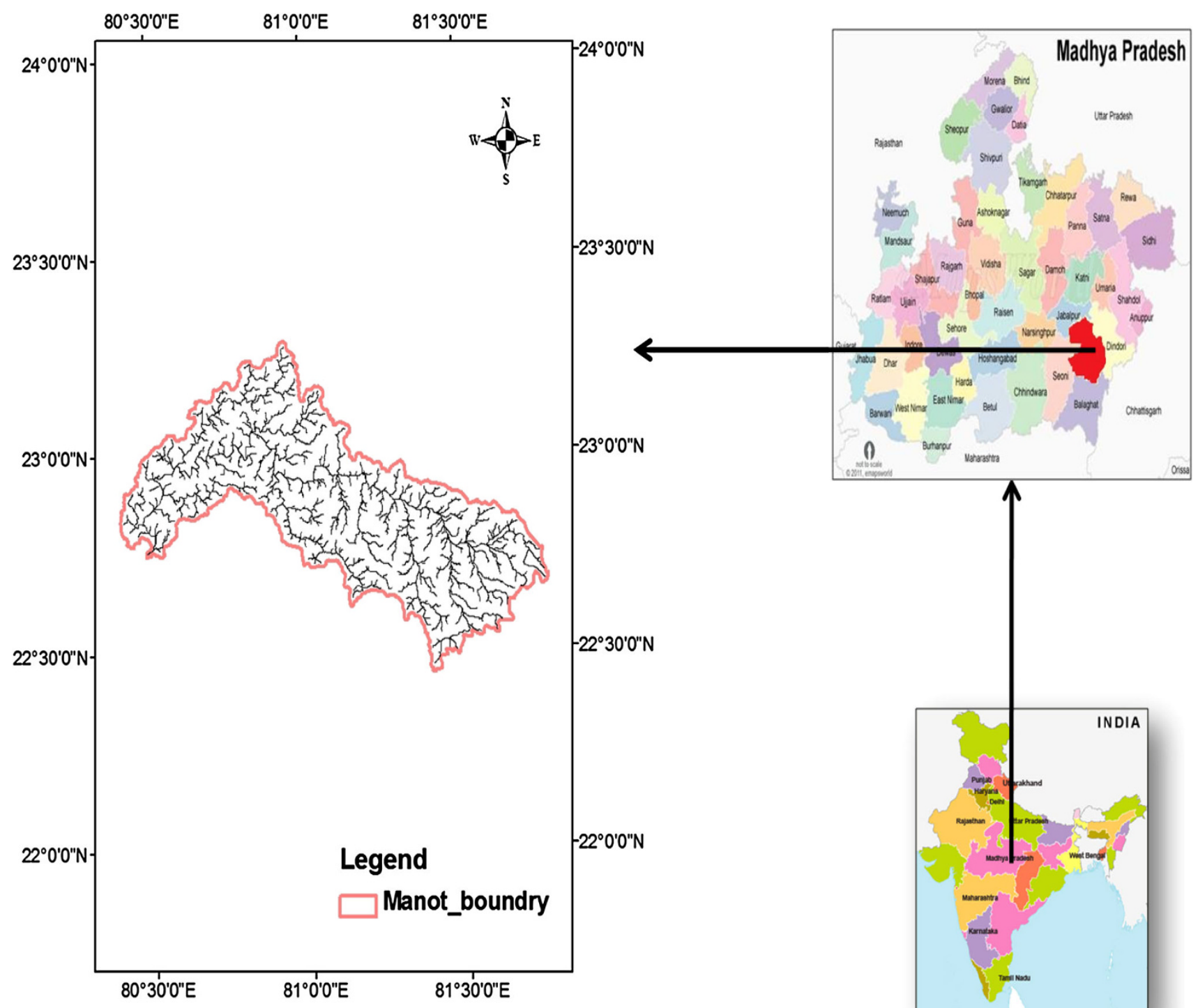

Fig. 1 Location map and stream network of Manot River catchment

stream. When two streams of first order join, an order two stream is created. When two streams of different orders join, the channel segment immediately downstream has a higher order of the two joining streams. The order of a basin is the order of the highest stream.

\section{Stream number $\left(N_{u}\right)$}

It is the number of stream segments of various orders and is inversely proportional to the stream order.

\section{Total stream length $\left(L_{a}\right)$}

It is the length of all the streams having order $u$. It indicates the contributing area of the basin of that order.
Main stream length

It is the length of the main stream having a maximum length.

Watershed perimeter $\left(P_{r}\right)$

It is the length of the watershed boundary.

Maximum length of the watershed $\left(L_{b}\right)$

It is the distance between the watershed outlet and the farthest point on the watershed. 
Fig. 2 Sub-watershed of the Manot River catchment

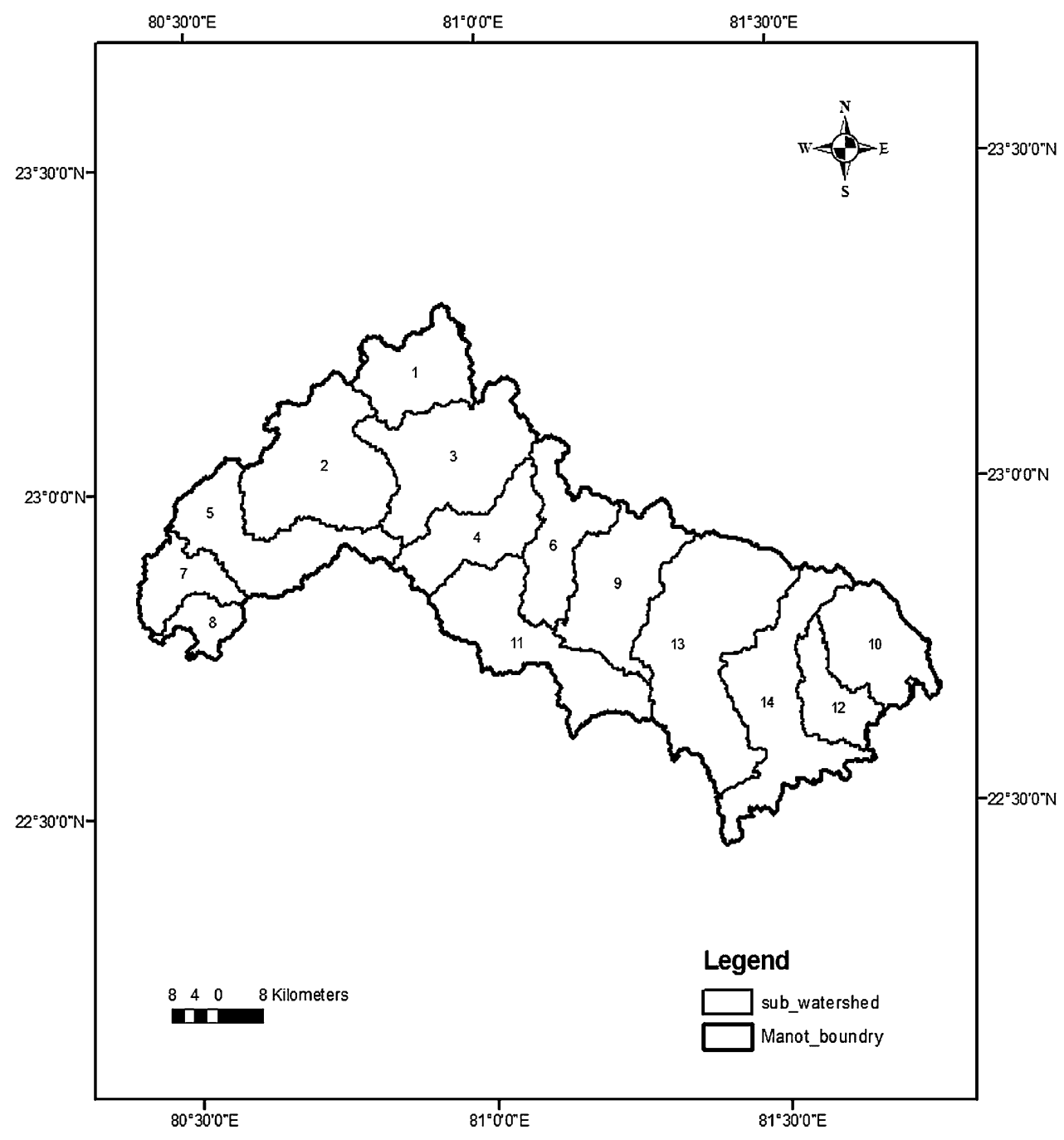

$R_{f}=\frac{A}{L_{b}^{2}}$

It is the ratio of the number of streams of a given order $u$ to the number of streams of higher order $u+1$.

\section{Elongation ratio $\left(R_{e}\right)$}

$R_{b}=\frac{N_{u}}{N_{u+1}}$

It is defined as the ratio between the diameter of a circle with the same area as that of the basin to the maximum length of the basin and is computed as

$R_{f}=\frac{2}{L_{b}} \sqrt{\frac{A}{\Pi}}$

The elongation ratio ranges from 0.6 to 1.0 over a wide variety of climatic and geological environments. Values nearing 1.0 are typical of regions of low relief, whereas values in the range of $0.6-0.8$ are generally associated with strong relief and steep ground slopes. Elongated basins with high bifurcations yield a low, but extended peak flow. 


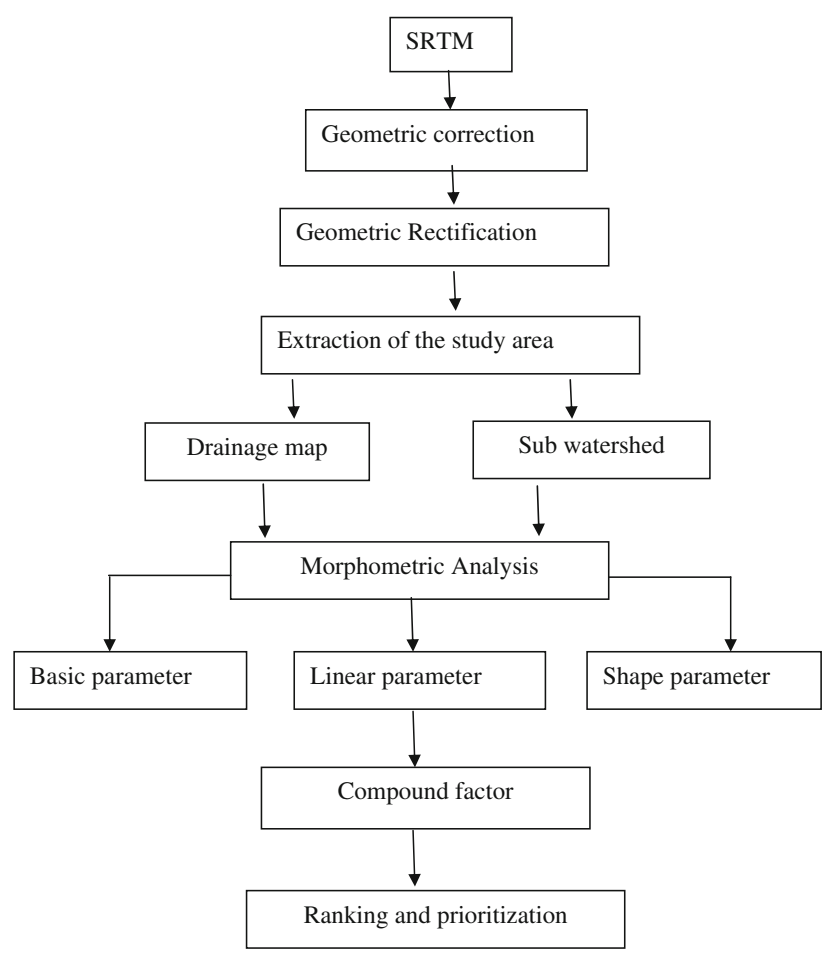

Fig. 3 Flowchart of the methodology used in this study

\section{Circulatory ratio $\left(R_{c}\right)$}

It is the ratio of the watershed area to the area of circle having an equal perimeter as the perimeter of the watershed $\left(P_{r}\right)$. Circular basins with low bifurcation ratio produce a sharp peak. It is computed as

$R_{c}=\frac{12.57 \mathrm{~A}}{P_{r}^{2}}$.

\section{Drainage density $\left(D_{d}\right)$}

Drainage density is one of the important indicators of the linear scale of land form in stream-eroded topography and is defined as the ratio of the total length of the streams of all orders of basin to the area of the basin. The drainage density, expressed in $\mathrm{km} / \mathrm{km}^{2}$, indicates closeness of spacing of channels, thus providing a quantitative measure of the average length of stream channel for the whole basin. Further, it also gives an idea of the physical properties of the underlying rocks. Low drainage density occurs in regions of highly resistant and permeable subsoil materials with dense vegetation and low relief, whereas high drainage density is prevalent in regions of weak, impermeable subsurface materials which are sparsely vegetated and have high relief (Strahler 1964).

\section{Drainage frequency $\left(D_{f}\right)$}

Drainage frequency is the number of streams per unit area of the basin. It mainly depends upon the lithology of the basin and reflects the texture of the drainage network.

Texture ratio $(T)$

It is the ratio of the maximum watershed relief to the perimeter of the watershed.

$T=\frac{H}{P_{r}}$.

Maximum watershed relief $(H)$

It is the maximum vertical distance between the lowest and highest points of a watershed. It is also known as total relief.

\section{Compactness coefficient $\left(C_{c}\right)$}

It given by Horton (1945) as

$T=0.2821 \frac{P^{0.5}}{A}$

For morphometric analysis, area, perimeter, maximum length of watershed, drainage network, stream length of each order and number of streams of each order and watershed relief values are required. These inputs were derived using GIS software. The necessary parameters for morphometric analysis were calculated by using the equations as discussed above, and with the above information the watershed is characterized.

\section{Prioritization of sub-watersheds}

The resource considerations for implementation of watershed management program or various other reasons pertaining to administrative or even political consideration may limit the implementation to few sub-watersheds. Even otherwise, it is always better to start management measures from the highest priority sub-watersheds, which makes it mandatory to prioritize the sub-watersheds available. Watershed prioritization is thus ranking of different subwatersheds according to the order in which they have to be taken for treatment and soil conservation measures. Hence, it was necessary to evolve a suitable mechanism for prioritizing the sub-watersheds.

Bali and Karale (1977) prioritized the sub-watersheds on the basis of sediment yield index (SYI) that requires soil map and other information. Morphometric parameters and SYI-based prioritization was carried out by Biswas et al. 
(1999). In this study, both the prioritization schemes had given identical priority. The study indicates that morphometric analysis could be used effectively for prioritization even without a soil map. To facilitate phase-wise implementation of watershed management program, all the subwatersheds were prioritized into four categories based on the percentage of the cultivated area and drainage density of each sub-watershed by Durbude et al. (2001) and Pandey et al. (2004). Further, these categories were ranked on the basis of average slope by Pandey et al. (2007). However, this prioritization scheme also requires several types of data. Javed et al. (2009) prioritized the sub-watersheds on the basis of morphometric parameters and land use/land cover. Both the prioritization schemes were given identical priority. However, in another study, Javed et al. (2011) found that most of the sub-watersheds were not of matching priority on the basis of the same prioritization scheme. This conflicting situation occurs due to variation in the cropping pattern and type of agriculture being practiced in the area.

Drainage analysis based on morphometric parameters is very important for sub-watershed prioritization, since it gives an idea about the basin characteristics in terms of slope, topography, soil condition, runoff characteristics, surface water potential, etc. Drainage network reflects the land-forming processes and thus gives the combined effect of soil, lithological formation, land cover, etc., and hence plays a major role in identifying the priority sub-watersheds for developmental work.

Watersheds are prioritized on the basis of morphometric parameters, Universal Soil Loss Equation (USLE), SYI, land use, land cover, etc. Several studies in the recent past have been done on prioritization of sub-watersheds and are discussed above. Morphometric analysis is one of the significant models for prioritization of sub-watersheds even without soil map and land use/land cover map. This model depends on the behavior of the total drainage system. The drainage pattern refers to spatial relationship among streams or rivers, which may be influenced in their erosion by inequalities of slope, soil, rock resistance, structure and geologic history of the region. For prioritization of subwatersheds in water resources management, the morphometric analysis uses some very crucial linear and shape morphometric parameters.

Linear parameters such as drainage density, stream frequency, bifurcation ratio and texture ratio have direct relationship with erodibility, whereas shape parameters such as elongation ratio, circulatory ratio, form factor and compactness ratio have an inverse relationship with erodibility (Nooka Ratnam 2005; Thakkar and Dhiman 2007; Kiran and Srivastava 2012). Greater values of linear parameters enhance the runoff potential and thereby the erodibility, whereas lower values of shape parameters give higher unit area sediment yield. Hence, ranking of each sub-watershed was carried out depending on the values of different geomorphological parameters. The highest value of $R_{b}, D_{d}, T$ and $D_{f}$ was given a rating of 1 , the next highest value was given a rating of 2 and so on, as these geomorphological parameters generally show positive correlation with soil erosion. The lowest value was rated last in the series of numbers (Biswas et al. 2002; Nooka Ratnam, 2005; Thakkar and Dhiman 2007). For $R_{f}, R_{e}, C_{c}$ and $R_{c}$, theleast value was given a rating of 1 , the next lowest value was given a rating of 2 and so on, as these parameters show negative correlation with soil erosion (Biswas et al. 2002; Nooka Ratnam 2005; Thakkar and Dhiman 2007). So, the prioritization rating of all the sub-watersheds of Manot watershed was carried out by calculating the compound parameter values. The sub-watershed with the lowest compound parameter value was given the highest priority.

\section{Result and discussion}

The study carried out has been divided into three sections. The first section deals with delineation of stream numbers, stream order and stream lengths in the study area using SRTM data along with delineation of watershed area, perimeter and length in GIS environment shown in Table 1. The second section deals with the various linear and shape morphometric parameters which characterize the sub-watersheds and lead to understanding the hydrological behavior of sub-watersheds and thereby soil erosion in the respective sub-watersheds. The third section deals with the prioritization of watersheds on the basis of these linear and shape morphometric parameters.

\section{Linear parameters}

Drainage parameters such as drainage density, stream frequency, bifurcation ratio and texture ratio are grouped under linear parameters and are discussed in the following.

\section{Drainage density $\left(D_{d}\right)$ and drainage frequency $\left(D_{f}\right)$}

In the present study, drainage density $\left(D_{d}\right)$ and drainage frequency $\left(D_{f}\right)$ are computed for all the sub-watersheds and are given in Table 2. After analysis of the drainage map, it was found that the Manot River catchment is of the eighthorder type and the drainage pattern is dendritic. Drainage frequency values of all the sub-watersheds have close correlation with drainage density indicating the increase in stream population with respect to increase in drainage density. High value of $D_{f}$ in the sub-watershed 2 produces more runoff compared to others. In general, it was observed over a wide range of geologic and climatic types 
Table 1 Sub-watershed-wise morphometric parameters

\begin{tabular}{|c|c|c|c|c|c|c|c|c|}
\hline \multirow[t]{2}{*}{ Sub-watershed } & \multirow{2}{*}{$\begin{array}{l}\text { Area } \\
\left(\mathrm{km}^{2}\right)\end{array}$} & \multirow{2}{*}{$\begin{array}{l}\text { Perimeter } \\
(\mathrm{km})\end{array}$} & \multicolumn{2}{|l|}{ Elevation } & \multirow{2}{*}{$\begin{array}{l}\text { Length of basin } \\
(\mathrm{km})\end{array}$} & \multirow{2}{*}{$\begin{array}{l}\text { Total relief } \\
(\mathrm{m})\end{array}$} & \multirow[t]{2}{*}{ No. of streams } & \multirow{2}{*}{$\begin{array}{l}\text { Total stream } \\
\text { length }(\mathrm{km})\end{array}$} \\
\hline & & & $\operatorname{Max}(\mathrm{m})$ & $\operatorname{Min}(\mathrm{m})$ & & & & \\
\hline 1 & 260.89 & 92.41 & 980 & 680 & 18.53 & 300 & 2,006 & 802.37 \\
\hline 2 & 522.51 & 129.61 & 900 & 520 & 26.21 & 380 & 3,577 & $1,595.05$ \\
\hline 3 & 478.65 & 132.19 & 1,040 & 600 & 26.51 & 440 & 3,614 & $1,487.95$ \\
\hline 4 & 263.12 & 100.31 & 1,000 & 620 & 20.22 & 380 & 2,006 & 856.69 \\
\hline 5 & 371.85 & 148.51 & 900 & 480 & 29.37 & 420 & 2,701 & $1,139.62$ \\
\hline 6 & 268.94 & 114.56 & 1,040 & 660 & 22.93 & 380 & 2,030 & 883.75 \\
\hline 7 & 161.73 & 82.80 & 760 & 460 & 15.44 & 300 & 1,166 & 503.14 \\
\hline 8 & 96.10 & 61.89 & 760 & 440 & 12.34 & 320 & 646 & 294.09 \\
\hline 9 & 381.26 & 123.18 & 1,020 & 680 & 22.85 & 340 & 2,823 & $1,238.00$ \\
\hline 10 & 291.04 & 91.44 & 1,134 & 760 & 19.40 & 374 & 2,215 & 958.21 \\
\hline 11 & 432.56 & 147.37 & 1,020 & 660 & 40.80 & 360 & 3,273 & $1,392.75$ \\
\hline 12 & 170.57 & 84.76 & 1,080 & 740 & 18.40 & 340 & 1,295 & $5,48.66$ \\
\hline 13 & 707.85 & 166.74 & 1,120 & 700 & 37.24 & 420 & 5,405 & $2,215.78$ \\
\hline 14 & 477.77 & 200.38 & 1,134 & 740 & 25.84 & 394 & 3,618 & $1,527.80$ \\
\hline
\end{tabular}

Table 2 Stream morphometric parameters

\begin{tabular}{lllllllll}
\hline Sub-watershed & $\begin{array}{l}\text { Bifurcation } \\
\text { ratio }\left(R_{b}\right)\end{array}$ & $\begin{array}{l}\text { Drainage } \\
\text { density }\left(D_{d}\right)\end{array}$ & $\begin{array}{l}\text { Stream } \\
\text { frequency }\left(F_{s}\right)\end{array}$ & $\begin{array}{l}\text { Circulatory } \\
\text { ratio }\left(R_{c}\right)\end{array}$ & $\begin{array}{l}\text { Form } \\
\text { factor }\left(R_{f}\right)\end{array}$ & $\begin{array}{l}\text { Elongation } \\
\text { ratio }\left(R_{e}\right)\end{array}$ & $\begin{array}{l}\text { Texture } \\
\text { ratio }(T)\end{array}$ & $\begin{array}{l}\text { Compactness } \\
\text { coefficient }\left(C_{c}\right)\end{array}$ \\
\hline 1 & 3.715 & 3.075 & 7.689 & 0.386 & 0.760 & 0.984 & 21.707 & 0.010 \\
2 & 4.314 & 3.053 & 6.846 & 0.393 & 0.761 & 0.984 & 27.599 & 0.006 \\
3 & 4.345 & 3.109 & 7.550 & 0.347 & 0.681 & 0.931 & 27.340 & 0.007 \\
4 & 3.827 & 3.256 & 7.624 & 0.331 & 0.644 & 0.905 & 19.998 & 0.011 \\
5 & 4.216 & 3.065 & 7.264 & 0.213 & 0.431 & 0.741 & 18.188 & 0.009 \\
6 & 3.859 & 3.286 & 7.548 & 0.259 & 0.512 & 0.807 & 17.720 & 0.011 \\
7 & 4.405 & 3.111 & 7.210 & 0.298 & 0.678 & 0.930 & 14.082 & 0.016 \\
8 & 4.032 & 3.060 & 6.722 & 0.317 & 0.631 & 0.897 & 10.438 & 0.023 \\
9 & 4.080 & 3.247 & 7.404 & 0.318 & 0.730 & 0.964 & 22.918 & 0.008 \\
10 & 3.967 & 3.292 & 7.611 & 0.440 & 0.773 & 0.993 & 24.225 & 0.009 \\
11 & 3.956 & 3.220 & 7.567 & 0.252 & 0.260 & 0.575 & 22.209 & 0.008 \\
13 & 3.696 & 3.217 & 7.592 & 0.300 & 0.504 & 0.801 & 15.278 & 0.015 \\
14 & 6.574 & 3.130 & 7.636 & 0.322 & 0.510 & 0.806 & 32.416 & 0.005 \\
\end{tabular}

that low $D_{d}$ was more likely to occur in regions of highly permeable subsoil material under dense vegetation cover and where relief was low. In contrast, high $D_{d}$ is favored in regions of weak or impermeable subsurface material, sparse vegetation and mountainous relief (Nag and Chakraborty 2003). In the present study, low value of $D_{d}$ for sub-watershed 2 indicates that it has highly resistant, impermeable subsoil material with dense vegetation cover and low relief. The sub-watershed with high value of $D_{d}$ indicates a well-developed network, which is conducive for quick disposal of runoff resulting in intense floods and also characterized by a region of weak subsurface materials, high relief and sparse vegetation.
Bifurcation ratio $\left(R_{b}\right)$

The bifurcation ratio $\left(R_{b}\right)$ reflecting the geological and tectonic characteristics of the watershed area were calculated for all 14 sub-watersheds and are given in Table 2 . These values are more or less normal in the sub-watersheds $1,4,6,10,11$ and 12 , as they range between 1 and 4 (Horton 1945). Higher values of $R_{b}$ for sub-watersheds indicates high runoff, low recharge and mature topography and are expected in the region of steeply dipping rock strata where narrow valley is confined between the ridges. The values of $R_{b}$ also indicate that the basin has suffered less structural disturbances. The variation in $R_{b}$ values among 
Table 3 Prioritization sub-watersheds using morphological parameters

\begin{tabular}{|c|c|c|c|c|c|c|c|c|c|c|}
\hline $\begin{array}{l}\text { Sub-watershed } \\
\text { No. }\end{array}$ & $\begin{array}{l}\text { Bifurcation } \\
\text { ratio }\left(R_{b}\right)\end{array}$ & $\begin{array}{l}\text { Drainage } \\
\text { density }\left(D_{d}\right)\end{array}$ & $\begin{array}{l}\text { Stream } \\
\text { frequency }\left(F_{s}\right)\end{array}$ & $\begin{array}{l}\text { Circulatory } \\
\text { ratio }\left(R_{c}\right)\end{array}$ & $\begin{array}{l}\text { Form } \\
\text { factor }\left(R_{f}\right)\end{array}$ & $\begin{array}{l}\text { Elongation } \\
\text { ratio }\left(R_{e}\right)\end{array}$ & $\begin{array}{l}\text { Texture } \\
\text { ratio }(T)\end{array}$ & $\begin{array}{l}\text { Compactness } \\
\text { coefficient }\left(C_{c}\right)\end{array}$ & $\begin{array}{l}\text { Compound } \\
\text { parameter }\end{array}$ & $\begin{array}{l}\text { Final } \\
\text { priority }\end{array}$ \\
\hline 1 & 13 & 10 & 1 & 12 & 13 & 12 & 7 & 6 & 9.25 & 12 \\
\hline 2 & 5 & 11 & 14 & 13 & 12 & 13 & 2 & 2 & 9.00 & 11 \\
\hline 3 & 4 & 9 & 8 & 11 & 9 & 9 & 3 & 3 & 7.00 & 6 \\
\hline 4 & 12 & 14 & 3 & 10 & 7 & 7 & 8 & 7 & 8.50 & 10 \\
\hline 5 & 6 & 12 & 11 & 2 & 2 & 2 & 9 & 5 & 6.13 & 3 \\
\hline 6 & 11 & 2 & 9 & 4 & 5 & 5 & 11 & 7 & 6.75 & 5 \\
\hline 7 & 2 & 8 & 12 & 5 & 8 & 8 & 13 & 9 & 8.13 & 8 \\
\hline 8 & 8 & 13 & 13 & 7 & 6 & 6 & 14 & 10 & 9.63 & 13 \\
\hline 9 & 7 & 3 & 10 & 8 & 11 & 11 & 6 & 4 & 7.50 & 7 \\
\hline 10 & 10 & 1 & 4 & 14 & 14 & 14 & 4 & 5 & 8.25 & 9 \\
\hline 11 & 9 & 4 & 7 & 3 & 1 & 1 & 5 & 4 & 4.25 & 2 \\
\hline 12 & 14 & 5 & 5 & 6 & 3 & 3 & 12 & 8 & 7.00 & 6 \\
\hline 13 & 1 & 7 & 2 & 9 & 4 & 4 & 1 & 1 & 3.63 & 1 \\
\hline 14 & 3 & 6 & 6 & 1 & 10 & 10 & 10 & 4 & 6.25 & 4 \\
\hline
\end{tabular}

the drainage basins are attributed to the differences in various stages of geomorphic development and topographic variations.

\section{Texture ratio $(T)$}

It is the total number of stream segments of all orders per perimeter of that area (Horton 1945). In the present study, texture ratio varied from 10.43 to 27.59 . The lower values of texture ratio indicate that the basin is plain with lower degree of slopes.

\section{Shape parameters}

In general, the shape of the basin affects the stream flow hydrography and peak flows. Important parameters such as form factor, circularity ratio, elongation ratio and compactness coefficient grouped under shape parameters were computed for all 14 sub-watersheds (Table 2) and are discussed below:

\section{Form factor $\left(R_{f}\right)$}

The value of form factor would always be $<0.7854$ (for perfectly circular basin). The smaller the value of form factor, the more elongated will be the basin. Basins with high form factor have high peak flows of shorter duration, whereas those with low form factor have lower peak flows of longer duration. In the present case, sub-watersheds have lower $R_{f}$ value $(0.26-0.76)$ indicating them to be elongated in shape and suggesting flatter peak flow for longer duration. Flood flows of such elongated basins are easier to manage than those of circular basin.

\section{Circulatory ratio $\left(R_{c}\right)$}

Circulatory ratio $\left(R_{c}\right)$ is influenced by the length and frequency of streams, geological structures, land use/land cover, climate, relief and slope of the basin. In the present case, circulatory ratios for sub-watersheds are $0.15-0.44$, indicating that the area is characterized by high relief and the drainage system is structurally controlled.

\section{Elongation ratio $\left(R_{e}\right)$}

The value of elongation ratio $\left(R_{e}\right)$ for sub-watersheds varies between 0.57 and 0.99 , indicating sub-watersheds to be elongated with high relief and steep slopes.

\section{Compactness coefficient $\left(C_{c}\right)$}

The compactness coefficient value for the whole study area is shown in Table 2. The highest value was found for subwatershed $8(0.023)$, while the lowest value was for subwatershed $13(0.005)$.

\section{Prioritization of sub-watersheds}

To facilitate the phase-wise implementation, all the subwatersheds are prioritized on the basis of morphometric analysis. The compound parameter values of the 14 subwatersheds of the Manot River catchment are calculated and prioritization rating is shown in Table 3. The 
sub-watershed 13 with a compound parameter value of 3.63 received the highest priority (one) with the next in priority being sub-watershed 11 , having a compound parameter value of 4.25 . The highest priority indicates the greater degree of erosion in the particular sub-watershed and it becomes a potential candidate for applying soil conservation measures. The final prioritized map of the study area is shown in Fig. 4. Thus, soil conservation measures can first be applied to sub-watershed 13 and then to others depending on their priority.

The implication of structures, degree and depth of weathering, and position of lithological horizons are profound and are represented in the present prioritization. Geological field conditions provide very significant validation to the morphometric parameter-based prioritization. The Manot watershed finds appreciable correlation with the basalts which contains intertrappeans which are easily erodible and contribute to sediment yield and also the horizons of spheroidial weathering. The frequency of vesicles are not uniform properties, and deeply penetrating joint areas cause deep weathering zones due to circulation of water, even before the onset of watershed formation. This initial heterogeneity has played an important role and caused variation in the transport mechanism and watershed formation. The sub watersheds which are coming on priority from 1st to 7th is in fact a combined response of the two different lithology in the Manot watershed. The hard and compact basalts produce very little sediment yield but
Fig. 4 Prioritized rank map of the Manot River catchment

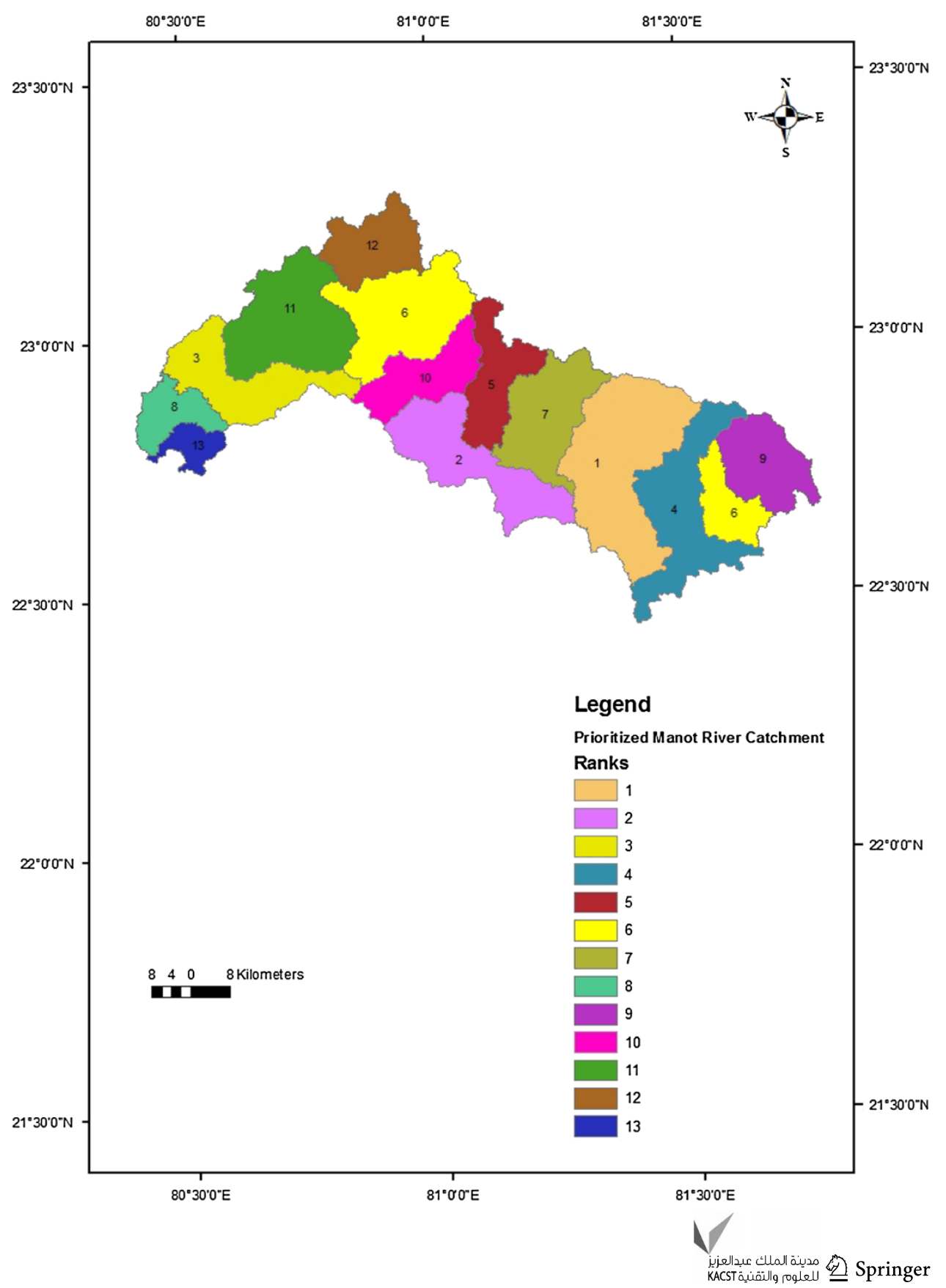




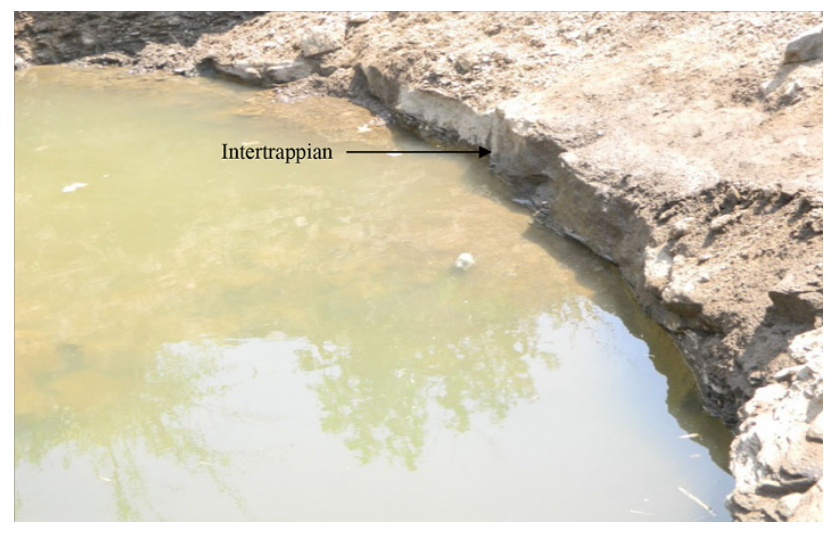

Fig. 5 Intertrappeans horizon containing water being recharged by the movement of water down the basaltic slope

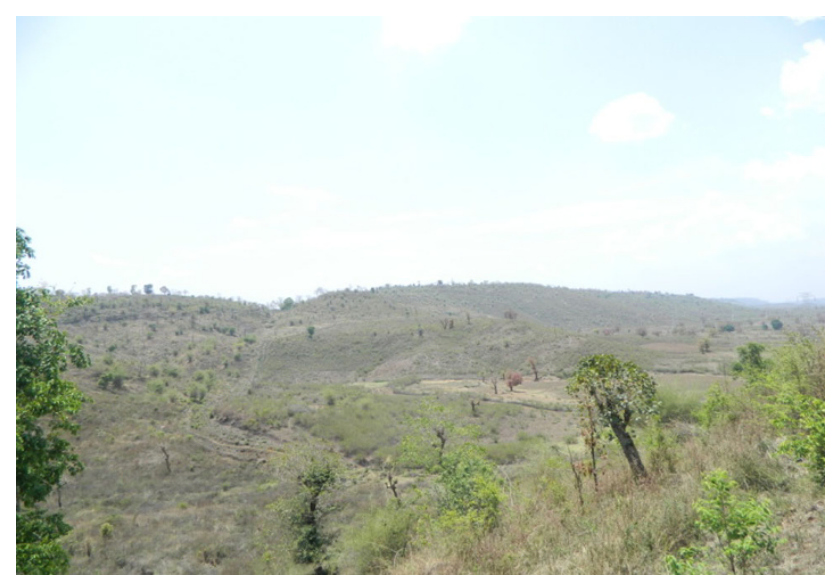

Fig. 6 Manot highlands facing the Narmada

high runoff conditions, and the intertrappeans sedimentary rocks which are soft and easily eroded contribute to the sediments. Higher runoff conditions have also diluted the sediment per unit volume. Therefore sub-watersheds which are of priority are 8th-14th; they occupy the areas of hard and compact basalts with little exposure to intertrappeans sedimentary rocks. It should be noted that intertrappeans rocks were formed due to sedimentation processes between two lava flows and represent the dormant periods between two eruptional episodes of Deccan lava. The intertrappeans generally consist clays, silts loose sand, etc. Therefore, the present morphological parameters-based prioritization fully agrees with the actual field conditions of the Manot watershed (Figs. 5, 6).

\section{Conclusion}

The quantitative morphometric analysis was carried out in 14 sub-watersheds of Manot catchment using GIS technique for determining the linear aspects such as stream order, bifurcation ratio, stream length and aerial aspects such as drainage density $\left(D_{d}\right)$, stream frequency $\left(F_{s}\right)$, form factor $\left(R_{f}\right)$, circulatory ratio $\left(R_{c}\right)$ and elongation ratio $\left(R_{e}\right)$. The conventional methods of morphometric analysis are time-consuming and error prone, while use of GIS technique allows for more reliable and accurate estimation of similar parameters of watersheds. The morphometric analysis of different sub-watersheds shows their relative characteristics with respect to hydrologic response of the watershed. The results of morphometric analysis show that sub-watershed 13 and 11 are prone to relatively higher erosion and soil loss. Geological field verification also agrees with the present morphological-based prioritization. Hence, suitable soil erosion control measures are required in these sub-watersheds to preserve the land from further erosion.

Open Access This article is distributed under the terms of the Creative Commons Attribution License which permits any use, distribution, and reproduction in any medium, provided the original author(s) and the source are credited.

\section{References}

Bali YP, Karale RL (1977) A sediment yield index for choosing priority basins. IAHS-AISH Publ 222:180

Bali R, Agarwal K, Nawaz AS, Rastogi S, Krishna K (2012) Drainage morphometry of Himalayan Glacio-fluvial basin, India: hydrologic and neotectonic implications. Environ Earth Sci 66(4):1163-1174. doi:10.1007/s12665-011-1324-1

Biswas S, Sudhakar S, Desai VR (1999) Prioritization of sub watershed based on morphometric analysis of drainage basin: a remote sensing and GIS approach. J. Indian Soc Remote Sens 22(3): $155-167$

Biswas S, Sudhakar S, Desai VR (2002) Remote sensing and geographical information system based approach for watershed conservation. J Surv Eng 128(3):108-124

Chaudhary RS, Sharma PD (1998) Erosion hazard assessment and treatment prioritization of Giri river catchment, North Himalayas. Indian J Soil Conserv 26(1):6-11

Dabral PP, Pandey A (2007) Morphometric analysis and prioritization of eastern Himalayan River basin using Satellite data and GIS. Asian J Geoinformatics 7(3):3-14

Durbude DG, Purandara BK, Sharma A (2001) Estimation of surface runoff potential of a watershed in semi arid environment-a case study. J Indian Soc Remote Sens 29(1-2):47-58

Horton RE (1945) Erosional development of streams and their drainage basins: a hydrophysical approach to quantitative morphology. Geol Soc Am Bull 56:275-370

Javed A, Khanday MV, Ahmed R (2009) Prioritization of subwatershed based on morphometric and land use analysis using remote sensing and GIS techniques. Indian Soc Remote Sens $37: 261-274$

Javed A, Khanday MY, Rais S (2011) Watershed prioritization using morphometric and Land Use Land Cover: a Remote sensing and GIS based approach. J Geol Soc India 78:63-75

Kiran VSS, Srivastava YK (2012) Check Dam construction by prioritization of micro watershed, using morphometric analysis as a Perspective of remote sensing and GIS for Simlapal Block, Bankura, W.B. Bonfring Int Ind Eng Manag Sci 2(1):20-31 
Miller JR, Craig KR (2010) Assessment of channel dynamics, instream structures and post-project channel adjustments in North Carolina and its implications to effective stream restoration. Environ Earth Sci 59(8):1681-1692

Nag SK, Chakraborty S (2003) Influence of rock type and structure development of drainage network in hard rock terrain. J Indian Soc Remote Sens 31(1):25-35

Nooka Ratnam K (2005) Check Dam positioning by prioritization of micro watershed using SYI model and morphometric analysisremote sensing and GIS perspective. J Indian Soc Remote Sens 33(1):25-38

Pandey A, Chowdary VM, Mal BC (2004) Morphological analysis and watershed management using GIS. Hydrology J 27(3 \& 4):71-84

Pandey VK, Pandey A, Panda SN (2007) Application of Remote Sensing and GIS for watershed characterization - a case study of Banikdin watershed (Eastern India). Asian J Geoinformatics 3(7):3-15

Prasad KSS, Gopi S, Rao SR (1992) Demarcation of priority macro watershed in Mahboobnagar district A.P. using remote sensing technique. In: Murlikrishnav IV (ed) Remote sensing application and GIS recent trends. Tata McGraw-Hill Publishing Co. Ltd., New Delhi, pp 180-186

Sanware PG, Singh CP, Karele RI (1988) Remote sensing application for prioritization of subwatershed using sediment yield and runoff indices in the catchment of Masani barrage (Sahibi) UNDP/FAO Project Technical report-13 of Remote sensing centre. AISLUS Government of India New Delhi

Sebestain M, Jayaraman V, Chandrashekher MG (1995) Space technology application for development of watershed. Technical Report. ISRO-HQ-TR-104-95. ISRO, Bangalore, pp. 1-41

Sharda D, RaviKumar MV, Venkatratnam L, Malleswara Rao TCh (1993) Watershed prioritization for soil conservation-a GIS approach. Geo Carto Int 8(1):27-34

Sharma SK, Tignath S, Mishra SK (2008) Morphometric analysis of drainage basin using GIS approach. JNKVV Res J 42(1):88-92

State Planning and Statistical Department (2010) State statistical report, Government of Madhya Pradesh

Strahler AN (1964) Quantitative geomorphology of drainage basins and channel networks. Section 4-II. In: Chow VT (ed) Handbook of applied hydrology. McGraw-Hill, New York, pp 4-39

Thakkar AK, Dhiman SD (2007) Morphometric analysis and prioritization of mini watersheds in Mohr watershed, Gujarat using Remote Sensing and GIS techniques. J Indian Soc Remote Sens 35(4):313-321

Youssef AM, Pradhan B, Hassan AM (2011) Flash flood risk estimation along the St. Katherine road, southern Sinai, Egypt using GIS based morphometry and satellite imagery. Environ Earth Sci 62(3):611-623 